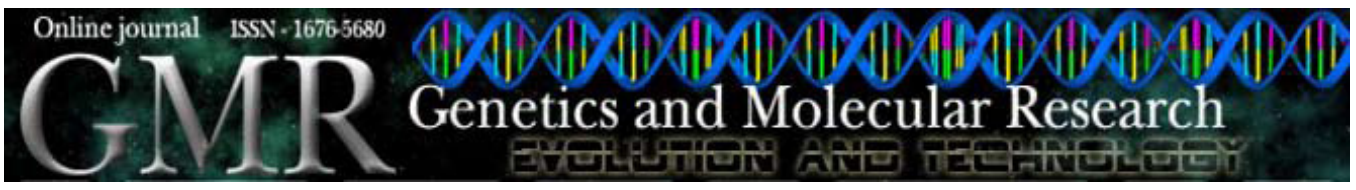

\title{
Leaf age affects the quality of DNA extracted from Dimorphandra mollis (Fabaceae), a tropical tree species from the Cerrado region of Brazil
}

\author{
P.A. Moreira ${ }^{1}$ and D.A. Oliveira ${ }^{2}$ \\ ${ }^{1}$ Departamento de Biologia Geral, Ecologia Evolutiva e Biodiversidade, \\ Instituto de Ciências Biológicas, Universidade Federal de Minas Gerais, \\ Belo Horizonte, MG, Brasil \\ ${ }^{2}$ Departamento de Biologia Geral, \\ Laboratório de Bioprospecção e Recursos Genéticos, \\ Universidade Estadual de Montes Claros, Montes Claros, MG, Brasil \\ Corresponding author: D.A. Oliveira \\ E-mail: dario.oliveira@unimontes.br
}

Genet. Mol. Res. 10 (1): 353-358 (2011)

Received August 23, 2010

Accepted November 27, 2010

Published March 1, 2011

DOI 10.4238/vol10-1gmr1030

\begin{abstract}
Isolation of high-quality DNA from plants, especially plants from the Cerrado, is notoriously difficult because of polysaccharides and secondary compounds produced by plants from this biome. DNA isolation and its quality may be compromised by chemical defenses such as tannins and phenols. Quantitative plant defenses tend to have a cumulative effect, increasing in concentration during leaf development, reducing DNA quality extracted in mature compared to young leaves. We report the effect of leaf age on DNA extraction of Dimorphandra mollis. Our working hypothesis was that the young leaves have more DNA than old leaves of the same individual because chemical defenses accumulate in older leaves. Young and old leaves were sampled from eight mature trees as well as leaves from eight seedlings in the north region of Minas Gerais State. Genomic DNA extraction followed the standard CTAB procedure. DNA isolation was very successful from young leaves of 16 individuals of $D$. mollis. The extracted DNA exhibited high quality and
\end{abstract}


the DNA quantity was also high, with an $\mathrm{A}_{260} / \mathrm{A}_{280}$ ratio above 1.8 , which is within the optimal sample range. In contrast, DNA isolation from old leaves was not successful. When the DNA was extracted from old leaves, the DNA was brownish, indicating contamination by phenolic compounds. These metabolites oxidize the DNA irreversibly, which hinders amplification of DNA by PCR by inhibiting the action of enzymes such as Taq polymerase. PCR performed with DNA from young leaves of $D$. mollis was successful and produced strong bands for RAPD markers.

Key words: "Fava d'anta"; DNA extraction; Cerrado; Metabolic compounds; Dimorphandra mollis

\section{INTRODUCTION}

Plant biodiversity research using molecular markers has increased for species from Brazil (Lemes et al., 2007; Moreira et al., 2009; Novaes et al., 2010; Souza and Lovato, 2010). These studies have used leaves of plants as the DNA source. For this kind of analysis highquality DNA is necessary for polymerase chain reaction (PCR). However, isolation of highquality DNA from plants, especially plants from the Cerrado, is notoriously difficult (Novaes et al., 2009). This problem has been attributed to content of polysaccharides and secondary compounds produced by plants from this biome (Couch and Fritz, 1990; Faleiro et al., 2003).

The Cerrado biome is considered to be one of the 34 hotspots for biodiversity conservation (Mittermeier et al., 2004). Many trees from the Cerrado are known for their potential for bioprospecting. Native plants have been used in folk medicine, search for new pharmaceuticals, the cosmetics industry, production of biofuels, and for other purposes (Oliveira et al., 2006). Many of these uses are possible because of secondary compounds produced by plants against natural enemies, such as herbivores (Coley et al., 1985).

DNA isolation and its quality may be compromised by chemical defenses such as tannins and total phenolics (Katterman and Shattuck, 1983). These compounds bind to DNA upon cell lysis and can be removed during DNA extraction procedures adding polyvinyl pyrrolidone and $\beta$-mercaptoethanol to the buffer (John, 1992). However, quantitative plant defences tend to have a cumulative effect, increasing in concentration during leaf development (Loyola and Fernandes, 1993; Coley and Barone, 1996; Cornelissen and Fernandes, 2001; Matsuki et al., 2004), thus reducing DNA quality extracted in mature compared to young leaves. This can be especially important for Cerrado plants, which produce large amounts of secondary compounds for defenses (Cornelissen and Fernandes, 2001).

The effect of chemical defenses against herbivore attacks has been shown in some studies, which reveal higher levels of secondary compounds in mature than in young plants (Del-Val and Dirzo, 2003; Boege, 2005; Boege and Marquis, 2006). Old plants are capable of maintaining stronger chemical defenses than young plants possibly because young individuals need to allocate their resources to early growth (Coley et al., 1985; Herms and Mattson, 1992; Elger et al., 2009).

In this paper, we report on the effect of leaf age in DNA extraction of Dimorphandra mollis Benth., a tropical tree species from the Cerrado. Our working hypothesis was that the young leaves have more DNA than old leaves of the same individual because of chemical 
defenses accumulated in older leaves.

\section{MATERIAL AND METHODS}

\section{Species tested}

Dimorphandra mollis Benth. is a tropical Leguminosae tree from the Cerrado, which has been greatly exploited because of its secondary compounds (Gomes and Gomes, 2000). D. mollis has a high economic value (Giuliano et al., 2005) because the flavonoid it contains, rutin, has been used by the pharmaceutical and cosmetic industries (Gomes and Gomes, 2000). Rutin has anti-oxidant, anti-tumoral, anti-diuretic, and anti-inflammatory properties. It increases the absorption of vitamin $\mathrm{C}$ in the body and the resistance of capillaries, preventing baldness and hemorrhoids (Yokozawa et al., 1997; Féres et al., 2006). Therefore, efforts are necessary to prevent the extinction of $D$. mollis by anthropogenic pressure since this species is responsible for $50 \%$ of the world production of rutin (Gomes and Gomes, 2000). The predatory extraction of trees can cause the deterioration of genetic diversity and genetic studies can be used to establish effective conservation and management measures for D. mollis.

\section{Plant material}

Young and old leaves were sampled from eight $D$. mollis adult individuals as well as leaves from eight juvenile individuals from $D$. mollis. The samples were kept on ice and then taken to the laboratory, where they were stored at $-20^{\circ} \mathrm{C}$ until DNA extraction.

\section{DNA extraction}

Genomic DNA extraction followed the standard CTAB procedure (Doyle and Doyle, 1987) slightly modified as suggested by Faleiro et al. (2003). About $1 \mathrm{~g}$ frozen leaves was macerated in a porcelain crucible with liquid $\mathrm{N}_{2}$. Part of the macerate was placed in a plastic tube and then $800 \mu \mathrm{L}$ buffer was added consisting of $100 \mathrm{mM}$ Tris-HCl, $\mathrm{pH}$ 8.0, $20 \mathrm{mM}$ ethylenediamine tetraacetic acid (EDTA), 2.8\% hexadecyltrimethylammonium bromide (CTAB), $1.3 \mathrm{M}$ $\mathrm{NaCl}, 1 \%$ polyvinylpyrolidone (PVP) and $0.2 \% \beta$-mercaptoetanol. The macerate was mixed with buffer and the tubes were kept in a water bath $\left(70^{\circ} \mathrm{C}\right)$ for $1 \mathrm{~h}$, and shaken every $10 \mathrm{~min}$. After that, $700 \mu \mathrm{L}$ chloroform:isoamyl-alcohol (CIA) $(24: 1, \mathrm{v} / \mathrm{v})$ was added and tubes were homogenized by gentle inversion for $10 \mathrm{~min}$ and centrifuged $\left(4^{\circ} \mathrm{C}\right)$ for $10 \mathrm{~min}$. The supernatant was transferred to new tubes and $55 \mu \mathrm{L} 7 \% \mathrm{CTAB}$ was added, and the CIA step was repeated. DNA was precipitated by adding $700 \mu \mathrm{L}$ cold isopropanol and tubes were incubated at $-20^{\circ} \mathrm{C}$ for $2 \mathrm{~h}$ and then centrifuged as before. The supernatant was discarded and the pellet was washed two times with cold $70 \%$ ethanol $(\mathrm{v} / \mathrm{v})$. After the last discard the pellet was dried at room temperature and DNA was resuspended in $150 \mu \mathrm{L}$ water with $40 \mu \mathrm{g} / \mathrm{mL}$ RNAse for $1 \mathrm{~h}$ at $37^{\circ} \mathrm{C}$.

\section{DNA quantification}

DNA quantification was performed by spectrophotometry at $260 \mathrm{~nm}$ (Sambrook et al., 1989). The purity of DNA was evaluated by the ratio of the absorbance at 260 and 280 
$\mathrm{nm}\left(\mathrm{A}_{260} / \mathrm{A}_{280}\right)$. The absorbance at $260 \mathrm{~nm}$ reflects DNA concentration and the ratio of $\mathrm{A}_{260} /$ $\mathrm{A}_{280}$ reflects the ratio of nucleic acids to proteins in the sample (Sambrook et al., 1989). DNA integrity was performed by electrophoresis on $0.8 \%$ agarose gels with $1 \mathrm{X}$ TBE buffer, stained with ethidium bromide and photographed under UV light.

\section{DNA amplification}

DNA extracted was tested by amplification on PCR with RAPD primers. Amplification products were electrophoretically separated on $1.5 \%$ agarose gels with 1X TBE buffer, stained with ethidium bromide and photographed under UV light. A 100-bp DNA ladder was used to estimate the molecular size of the fragments.

\section{RESULTS AND DISCUSSION}

DNA isolation was very successful from young leaves of 16 individuals of D. mollis. The DNA extracted exhibited high quality (Figure 1) and the DNA quantity was also high with an $\mathrm{A}_{260} / \mathrm{A}_{280}$ ratio above 1.8, which is within the optimal sample range (Sambrook et al., 1989). In contrast, DNA isolation from old leaves was not successful (Figure 1). During the DNA extraction from old leaves it was brownish, indicating contamination by phenolic compounds. These metabolites oxidize the DNA irreversibly, which hinders amplification of DNA by PCR by inhibiting the action of enzymes such as Taq polymerase (Romano and Brasileiro, 1999).

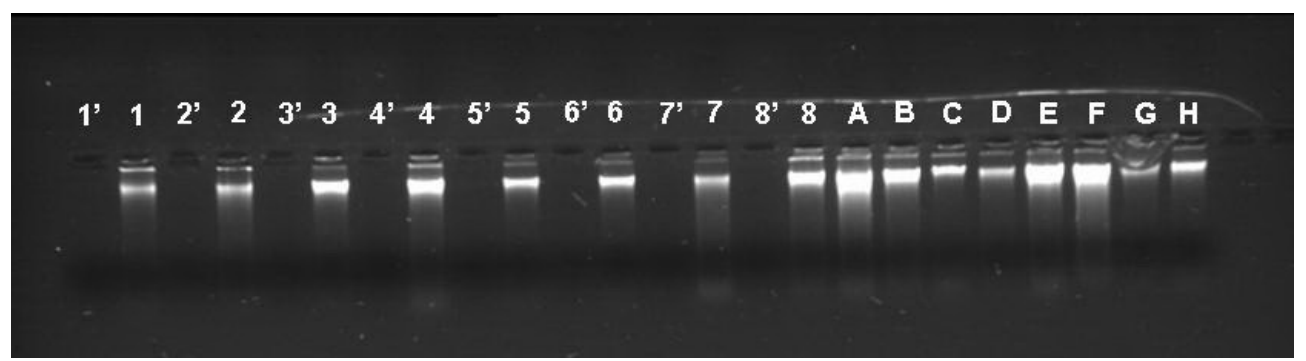

Figure 1. Total DNA genomic from Dimorphandra mollis. Old leaves are represented by lanes 1 ' to 8 ' and young leaves of the same trees are represented by lanes 1 to 8 . Young leaves from juveniles are represented by lanes $A$ to $H$.

Many trees from the Cerrado are used in the pharmaceutical and cosmetics industry, such as D. mollis, because of secondary compounds found in these plants. In fact, D. mollis is rich in the flavonoid rutin, which makes this tree the main source of rutin in Brazil (Gomes, 1998). The flavonoid is a secondary compound that could be responsible for the absence of nucleic acids during DNA extraction since phenolic metabolites bind to DNA and oxidize the DNA irreversibly (John, 1992; Romano and Brasileiro, 1999). Furthermore, old leaves accumulate chemical metabolites to defend plants against enemies, like insect herbivores that injure leaves. However, since young leaves need to grow they allocate their resources to growth and not to defenses.

The eight juveniles of $D$. mollis exhibit good quality and quantity of DNA (Figure 1). Juvenile individuals need to allocate their resources to early growth so their leaves do not have chemical compounds to defend against enemies yet.

PCR performed with DNA from young leaves of D. mollis was successful and pro- 
duced strong bands for RAPD markers (Figure 2). So, the DNA obtained from young leaves was pure enough to be appropriate for PCR amplifications. Novaes et al. (2009) was unable to produce bands of $D$. mollis in a PCR test for chloroplast and nuclear regions, the $p s b A$-trhH and the internal transcribed spacer region of the rRNA, respectively. The absence of bands could be associated with chemical compounds present in the leaves used.

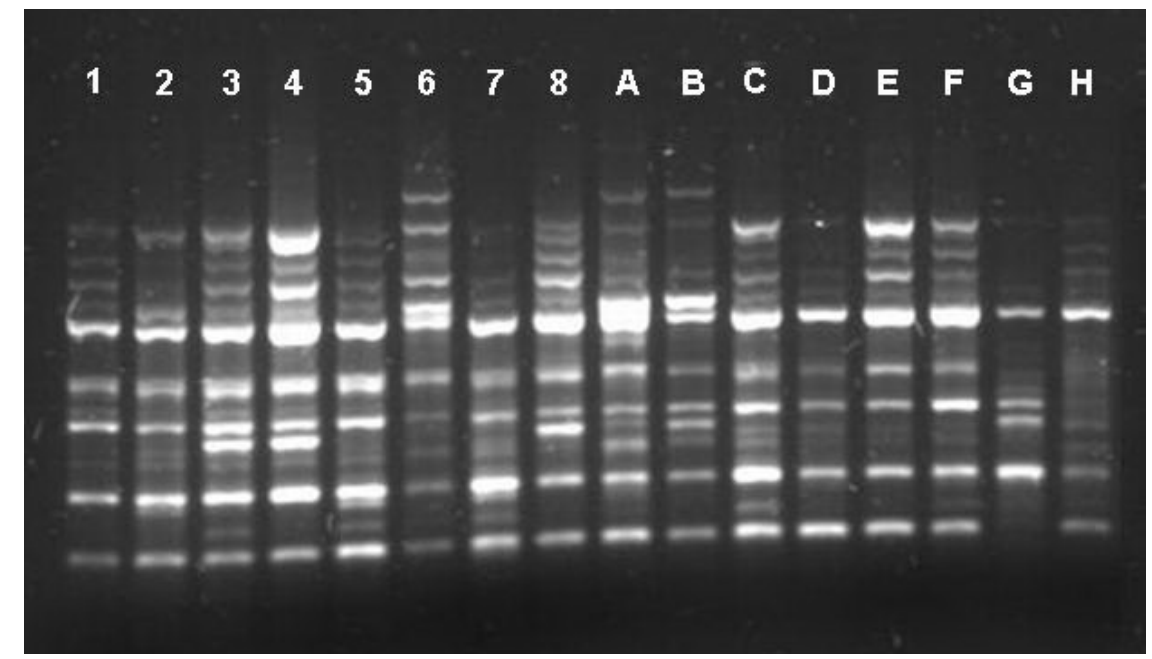

Figure 2. Amplification of RAPD markers from Dimophandra mollis DNA extracted from young leaves. The codes of samples are given in Figure 1.

DNA isolation is a very important step for molecular analyses and could be obtained from leaves of different ages and even bark (Novaes et al., 2009). The choice of DNA sources will be specific to each species and tests of DNA sources need to be performed (old or young leaves, barks or roots) before field work is conducted to collect samples. These results are very important for future works of conservation genetics with Dimorphandra mollis and other species from the Cerrado that produce much phenolic metabolites since their leaves are a necessary DNA source.

\section{ACKNOWLEDGMENTS}

We thank M.F.B. Paula and L.A. Rodrigues for their kind help in laboratory work and R.F. Braga for help in field work. We thank UNIMONTES for logistical support. Research supported by FAPEMIG, whose assistance we gratefully acknowledge.

\section{REFERENCES}

Boege K (2005). Herbivore attack in Casearia nitida influenced by plant ontogenetic variation in foliage quality and plant architecture. Oecologia 143: 117-125.

Boege K and Marquis RJ (2006). Plant quality and predation risk mediated by plant ontogeny: consequences for herbivores and plants. Oikos 115: 559-572.

Coley PD and Barone JA (1996). Herbivory and plant defences in tropical forests. Annu. Rev. Ecol. Syst. 27: 305-335.

Coley PD, Bryant JP and Chapin FS III (1985). Resource availability and plant antiherbivore defense. Science 230: 895-899. Cornelissen TG and Fernandes GW (2001). Defence, growth and nutrient allocation in the tropical shrub Bauhinia brevipes 
(Leguminosae). Austral Ecol. 26: 246-253.

Couch JA and Fritz PJ (1990). Isolation of DNA from plants high in polyphenolics. Plant Mol. Biol. Rep. 8: 8-12.

Del-Val E and Dirzo R (2003). Does ontogeny cause changes in the defensive strategies of the myrmecophyte Cecropia peltata? Plant Ecol. 169: 35-41.

Doyle JJ and Doyle JL (1987). A rapid DNA isolation procedure for small quantities of fresh leaf tissue. Phytoch. Bull. 19: 11-15.

Elger A, Lemoine DG, Fenner M and Hanley ME (2009). Plant ontogeny and chemical defence: older seedlings are better defended. Oikos 118: 767-773.

Faleiro FG, Faleiro ASG, Cordeiro MCR and Karia CT (2003). Metodologia para operacionalizar a extração de DNA de espécies nativas do cerrado visando a análises moleculares. Comunicado Técnico 92: 1-5. Embrapa-Cerrado, Brasília.

Féres CA, Madalosso RC, Rocha OA, Leite JP, et al. (2006). Acute and chronic toxicological studies of Dimorphandra mollis in experimental animals. J. Ethnopharmacol. 108: 450-456.

Giuliano I, Silva TGM, Napoleão R, Gutiérrez AH, et al. (2005). Fungus identification on Dimorphandra mollis seeds and the effect of different treatments. Fitopatol. Bras. 30: 553.

Gomes LJ (1998). Extrativismo e Comercialização da Fava d'anta (Dimorphandra spp): Um Estudo de Caso na Região de Cerrado de Minas Gerais. Master's thesis, UFLA, Lavras.

Gomes LJ and Gomes MAO (2000). O extrativismo e biodiversidade: o caso da fava d'anta. Cienc. Hoje 27: 66-69.

Herms DA and Mattson WJ (1992). The dilemma of plants: to grow or defend. Q. Rev. Biol. 67: 283-335.

John ME (1992). An efficient method for isolation of RNA and DNA from plants containing polyphenolics. Nucleic Acids Res. 20: 2381.

Katterman FR and Shattuck VI (1983). An effective method of DNA isolation from the mature leaves of Gossypium species that contain large amounts of phenolic terpenoids and tannins. Prep. Biochem. 13: 347-359.

Lemes MR, Grattapaglia D, Grogan J, Proctor J, et al. (2007). Flexible mating system in a logged population of Swietenia macrophylla King (Meliaceae): implications for the management of a threatened Neotropical tree species. Plant Ecol. 192: 169-179.

Loyola R and Fernandes GW (1993). Herbivory on Kielmeyra coriacea (Guttiferae): the effects of plant age, leaf development and quality. Rev. Bras. Biol. 53: 295-304.

Matsuki S, Sano Y and Koike T (2004). Chemical and physical defence in early and late leaves in three heterophyllous birch species native to northern Japan. Ann. Bot. 93: 141-147.

Mittermeier RA, Gil PR, Hoffmann J, Pilgrim J, et al. (2004). Hotspots Revisited: Earth's Biologically Richest and Most Endangered Terrrestrial Ecoregions. Cemex, Conservation International and Agrupacion Sierra Madre, Monterrey.

Moreira PA, Fernandes GW and Collevatti RG (2009). Fragmentation and spatial genetic structure in Tabebuia ochracea (Bignoniaceae) a seasonally dry Neotropical tree. Forest Ecol. Manag. 258: 2690-2695.

Novaes RM, Rodrigues JG and Lovato MB (2009). An efficient protocol for tissue sampling and DNA isolation from the stem bark of Leguminosae trees. Genet. Mol. Res. 8: 86-96.

Novaes RM, De Lemos Filho JP, Ribeiro RA and Lovato MB (2010). Phylogeography of Plathymenia reticulata (Leguminosae) reveals patterns of recent range expansion towards northeastern Brazil and southern Cerrados in Eastern Tropical South America. Mol. Ecol. 19: 985-998.

Oliveira DA, Moreira PA, Melo Júnior AF and Pimenta MAS (2006). Potential of plants biodiversity of the north region of Minas Gerais State. Unimontes Cient. 8: 23-33.

Romano E and Brasileiro ACM (1999). Extração de DNA de plantas. Biotecnol. Cienc. Desenvolv. 2: 40-43.

Sambrook J, Fritsch EF and Maniats T (1989). Molecular Cloning: a Laboratory Manual. Cold Spring Harbor Laboratory Press, New York.

Souza HAV and Lovato MB (2010). Genetic diversity and structure of the critically endangered tree Dimorphandra wilsonii and of the widespread in the Brazilian Cerrado Dimorphandra mollis: implications for conservation. Biochem. Syst. Ecol. 38: 49-56.

Yokozawa T, Dong E, Leiu ZW and Shimizu M (1997). Antioxidant activity of flavones and flavonols in vitro. Phytother. Res. 11: 446-449. 